\title{
The Effects of Antiepileptic Drugs on Pediatric Cognition, Mood, and Behavior
}

\author{
Khalid I. Afzal ${ }^{1}$ Seeba Anam ${ }^{1}$ Scott J. Hunter ${ }^{1,2}$ \\ 1 Department of Psychiatry and Behavioral Neuroscience, \\ The University of Chicago, Chicago, Illinois, United States \\ 2 Department of Pediatrics, The University of Chicago, Chicago, \\ Illinois, United States \\ J Pediatr Epilepsy 2017;6:3-18.
}

\begin{abstract}
Address for correspondence Khalid I. Afzal, MD, Department of Psychiatry and Behavioral Neuroscience, The University of Chicago, 5841 South Maryland Avenue, MC 3077, Chicago, IL 60457, United States (e-mail: kafzal@uchicago.edu).
\end{abstract}

\begin{abstract}
Keywords

- antiepileptic drugs

- mood

- behavior

- cognition

- adverse effects

In the past three decades, several new antiepileptic drugs (AEDs) have been marketed across the world, although with a surprisingly modest improvement in overall seizure control. During the same period, the use of AEDs as mood stabilizing or impulse control agents has been trending upwards, due to a notable increase in comorbid mood and behavior disorders in children, and a desire to address these pharmacologically. AEDs have been frequently associated with adverse mood and behavior changes, along with neuropsychiatric effects on attention, memory, and cognition. In this review, we discuss the use and adverse effects of the first- (e.g., barbiturates, carbamazepine, ethosuximide, phenytoin, valproate), second- (e.g., clobazam, felbamate, gabapentin, lamotrigine, levetiracetam, oxcarbazepine, pregabalin, tiagabine, topiramate, stiripentol, vigabatrin, zonisamide), and third- (e.g., brivaracetam, eslicarbazepine acetate, lacosamide, perampanel, retigabine, rufinamide) generation AEDs in pediatric mood and behavior disorders. We also address what is currently known about the potential longterm neuropsychiatric consequences of AEDs. The distinction between the U.S. Food and Drug Administration-approved drugs versus off-label use of these drugs in the pediatric population is also examined.
\end{abstract}

\section{Introduction}

Since the description of epileptic phenomenon in Babylonian cuneiform tablets more than 3,000 years ago, human beings have been fascinated with the etiology and treatment of seizures. ${ }^{1}$ Hippocrates was arguably the first, in $450 \mathrm{BC}$, to describe the proposed natural or physical causes underlying the occurrence of seizures and he led the search for physical or medical cures to counter the age-old spiritual healing practices that addressed seizures as reflecting suspected demonic possession. ${ }^{2}$ The dawn of antiepileptic drug (AED) therapy, however, began in 1857 with the mention of potassium bromide as a potential treatment for "hysterical epilepsy connected with the menstrual period," published in the Lancet. $^{3,4}$ In 1912, the use of newly synthesized phenobarbi-

received

February 1, 2015 accepted after revision

March 21, 2016

published online

July 1,2016 tal as a tranquilizer in epileptic patients was linked to the decrease of their seizure frequency. The following 60 years witnessed the second phase in the evolution of AED use, which included the development of phenytoin, primidone, ethosuximide, benzodiazepines, carbamazepine, and sodium valproate. In the past three decades, considered to be the modern era of AED development, more than 28,000 compounds have been screened as AEDs. ${ }^{3}$

Unfortunately, as will be further discussed, while this explosion of new AEDs has not fully translated into better seizure control for refractory seizures, there has been important improvements in the management of seizures overall. However, the secondary use of AEDs in mood and behavior disorders has increased manifold. ${ }^{2}$ This article aims to discuss the use and effects of AEDs in pediatric mood and behavior
Copyright $\odot 2017$ by Georg Thieme Verlag KG, Stuttgart · New York
DOI http://dx.doi.org/ 10.1055/s-0036-1584935. ISSN 2146-457X.
Evaluation in Children with Epilepsy;

Guest Editors: Scott J. Hunter, PhD, and Megan N. Scott, PhD 
disorders, along with the long-term consequence of AEDs on developing cognition and regulatory control.

\section{AEDs and Mood and Behavior Disorders}

The Diagnostic and Statistical Manual of Mental Disorder (DSM-5; APA 2013), categorizes mood and behavior disorders as the following ${ }^{5}$ :

1. Bipolar and related disorders
a. Bipolar I disorder
b. Bipolar II disorder
c. Cyclothymia

2. Disruptive, impulse-control, and conduct disorders
a. Oppositional defiant disorder
b. Intermittent explosive disorder
c. Conduct disorder

Substance/medication-induced bipolar and related disorders are not included in this article due to their presumed different etiological presentation.

Along with the antipsychotic medications, such as olanzapine, risperidone, and aripiprazole, the U.S. Food and Drug Administration (FDA) has approved several AEDs for medication management of mood and behavior disorders. ${ }^{6,7}$ Perucca and Mula divide AEDs into three generations (see - Table 1). ${ }^{8}$ The older, or traditional AEDs, were the only medications available to treat epilepsy before $1994 . .^{9}$ Since then there has been an explosion of new AEDs coming into the treatment pipeline, although there remains only limited data to suggest that epilepsy control has substantially improved. ${ }^{8,9}$ The mechanism of action of these drugs is suggested, but still uncertain, due to the varying molecular targets in the brain that may facilitate impact; these consist of $\gamma$-aminobutyric acid (GABA), glutamate, N-methyl-Daspartate receptor (NMDA)/ $\alpha$-amino-3-hydroxy-5-methyl-4isoxazolepropionic acid receptor, voltage-gated sodium and calcium channels and serotonin neurotransmitters and receptors. ${ }^{10-12}$ Furthermore, most of the available AEDs work on more

Table 1 Antiepileptic drugs currently in market

\begin{tabular}{|l|l|l|}
\hline First generation & Second generation & Third generation \\
\hline Barbiturates & Clobazam & Brivaracetam \\
\hline Benzodiazepines & Felbamate & $\begin{array}{l}\text { Eslicarbazepine } \\
\text { acetate }\end{array}$ \\
\hline Carbamazepine & Gabapentin & Lacosamide \\
\hline Ethosuximide & Lamotrigine & Perampanel \\
\hline Phenytoin & Levetiracetam & Retigabine \\
\hline Valproate & Oxcarbazepine & Rufinamide \\
\hline & Pregabalin & \\
\hline & Tiagabine & \\
\hline & Topiramate & \\
\hline & Stiripentol & \\
\hline & Vigabatrin & \\
\hline & Zonisamide & \\
\hline
\end{tabular}

than one receptor or neurotransmitter system and likely to create either a synergistic or antagonistic complex interaction, or a combination of both, when utilized. ${ }^{13}$

FDA approved indications of AEDs in mood and behavior disorders are limited and listed in - Table $2 .^{6,7}$ It is of particular note that no AED is currently FDA approved for use in pediatric mood and behavior disorders, although they are indicated in different types of pediatric seizure disorders. ${ }^{6}$ Tran et al, published an interesting account of the national trends of anticonvulsant use in pediatric population in the United States ${ }^{14}$ and found that during the period of 1996 through 2009, along with "seizure and convulsive" diagnoses, AEDs were increasingly prescribed in psychiatric conditions such as attention-deficit/hyperactivity disorder (ADHD), disruptive behavior disorder, conduct disorder, oppositional defiant disorder, bipolar disorder, depression and anxiety disorders. The number of prescriptions for the AEDs essentially doubled during the course of 14 years, regardless of the indication of use, however, there was no statistically significant change in the number of visits related to seizure disorders. Among other possibilities, this finding could suggest that AEDs have been increasingly prescribed to manage conditions other than seizures such as pediatric mood and behavior disorders. The authors also note a statistically significant trend of off-label use of AEDs especially in disruptive behavior disorder. Disruptive behavior disorder (or disruptive behavior disorder not otherwise specified) was a part of the "attention-deficit and disruptive behavior disorders" in the Diagnostic and Statistical Manual of Mental Disorder (DSM-IV-TR; APA 2000); it has now been placed in a separate category of "disruptive, impulse-control and conduct disorders" in DSM-5., 15 Over the course of the studied period, there was a notable decline of divalproex (Depakote, Abbott Laboratories, Lake Bluff, Illinois, United States) use in pediatric psychiatric conditions and a trend of off-label increased use of lamotrigine. ${ }^{14} \mathrm{~A}$ similar trend has been reported in a recent publication from Italy, showing an increasing use of valproic acid and lamotrigine in mood disorders during a period of 2005 to $2011^{16}$ in that country.

Before discussing individual AEDs, it is important to review the concept of "off-label" use. Off-label use is when a medication is prescribed outside the terms of its product license or marketing authorizations, which in the United Kingdom is

Table 2 FDA-approved indications of AEDs in mood and behavior disorders

\begin{tabular}{|l|l|}
\hline Medications & FDA-approved indications \\
\hline Carbamazepine & $\begin{array}{l}\text { Acute manic and mixed episodes in } \\
\text { bipolar I disorder in } \geq 18 \mathrm{y}\end{array}$ \\
\hline Lamotrigine & $\begin{array}{l}\text { Maintenance treatment of bipolar } \\
\text { disorder in } \geq 18 \mathrm{y}\end{array}$ \\
\hline Valproate & $\begin{array}{l}\text { Mania associated with bipolar } \\
\text { disorder in } \geq 18 \mathrm{y}\end{array}$ \\
\hline
\end{tabular}

Abbreviations: AEDs, antiepileptic drugs; FDA, Food and Drug Administration. 
defined as the terms of a medication use including its indications, recommended doses, contraindications, and special warnings and precautions. ${ }^{17}$ In the United States, off-label drug use involves prescribing currently available and marketed medications, but for an indication (e.g., a disease or a symptom) that has never received FDA approval. ${ }^{18,19}$ For example, Leslie et al identified that $60.2 \%$ of a total of 279,778 veterans who received antipsychotic medications in the year 2007 had no record of a diagnosis for which these drugs were approved. ${ }^{20}$ In pediatric populations, off-label use of medication is estimated at 50 to $70 \%{ }^{21}$ Haw and Stubbs argue that although the off-label use of drugs, including mood-stabilizers, has potential benefits for the patients, informed consent and assent of the patients and their parents regarding the off-label use is required, and that more robust clinical monitoring for side effects is warranted in such situations. ${ }^{22}$

We have divided our discussion of the AEDs being used with psychiatric conditions into two sections. The first section reviews the current use of AEDs in mood and behavior disorders, and offers guidelines for their consideration while the second section focuses on the psychiatric and neuropsychiatric adverse effects of AEDs on mood, behavior, and cognition.

\section{Use of AEDs in Mood and Behavior Disorders}

\section{First-Generation AEDs}

\section{Barbiturates}

Barbiturates potentiate GABAergic neurotransmission by acting as positive allosteric modulators of $\mathrm{GABA}_{\mathrm{A}}$ receptors. Phenobarbital is the most widely used AED in the world. It has a long halflife $\left(\mathrm{T}_{1 / 2}\right)$ up to 3 to 5 days in adults and 1.5 days in children. ${ }^{23}$ Other barbiturates include primidone, butobarbital, pentobarbital, secobarbital, and thiopental, among others. They are divided according to the $\mathrm{T}_{1 / 2}$ into long, medium, short, and very short acting barbiturates. Common indications are seizure disorders, anesthesia, headache, anxiety, insomnia, essential tremors, and delirium tremens associated with alcohol withdrawal. ${ }^{8,16}$ Barbiturates are known inducers of enzymes and can decrease the level of other medications. They are not primarily used in mood and behavior disorders, however, exert significant effects, including depression, suicidal ideation, paradoxical aggression, etc., as discussed in the next section.

\section{Carbamazepine}

Carbamazepine blocks sodium-channel and is approved by the FDA for its use in manic and mixed episodes of bipolar I disorder in $\geq 18$ years (-Table 2). Findling and Ginsberg demonstrated the efficacy of carbamazepine extendedrelease formulation in an open-label pediatric trial of bipolar I disorder in a manic or mixed episode. ${ }^{24}$ Around $57 \%$ of the subjects, including 58 children and 97 adolescents showed a reduction of more than $50 \%$ in young mania rating scale. Schneider et al, reported a normalization of activation of right Brodmann area 10 in 11 manic youths when compared with 10 age-matched controls in their recent study. ${ }^{25}$ There is no evidence of the use of carbamazepine in schizophrenia or other psychotic disorders. ${ }^{26}$

\section{Ethosuximide}

Ethosuximide blocks thalamic " $T$ " type calcium channels, an effect possessed by drugs that are effective against absence seizures. ${ }^{27}$ It is not indicated for its use in mood and behavior disorders.

\section{Phenytoin}

Phenytoin blocks frequency and use and voltage-dependent neuronal sodium channels, thus limiting the repetitive firing of action potentials. Bersudsky demonstrated its efficacy as an antimanic agent in adults' bipolar disorder that was comparable to other anticonvulsants. ${ }^{28}$ Another proposed mechanism of its antimanic action was through the inhibition of p-glycoprotein pump that in turn increases the concentration of cortisol in brain tissue and thereby the availability of cortisol at the central glucocorticoid receptor. Interestingly, it is reported that phenytoin can block the hypomanic effects of prescription corticosteroids in patients with allergies or pulmonary or rheumatological illnesses. ${ }^{29}$ Phenytoin is a P450 enzyme inducer and can affect the concentrations of concomitant medications such as carbamazepine.

\section{Valproate (Divalproex)}

Multiple mechanisms have been reported for the proposed action of valproate. They include increased brain GABAergic inhibitory activity, reduction of cortical excitability, and potentiation of high-frequency repetitive firing of $\mathrm{Na}^{+}$dependent action potentials through blockade of $\mathrm{Na}^{+}$channels. ${ }^{13,27,30}$ Masuch et al, recently described its role in microglial neuroprotection by a novel mechanism involving tumor necrosis factor- $\alpha$ release. ${ }^{31}$ It is FDA approved for the treatment of mania with bipolar disorder in $\geq 18$ years. Liu et al, discuss eight open-label and three double-blind studies of Depakote in pediatric bipolar disorder. ${ }^{32}$ Pavuluri et al demonstrated a differential engagement of fronto-striato-temporal circuitry in pediatric mania in the functional magnetic resonance imaging study. ${ }^{33}$ Total subjects of 36 were divided into healthy control, risperidone, and Depakote groups. Under emotional duress, divalproex group enhanced activation in a frontotemporal striatum circuit while risperidone increased activation in the dopamine $\left(D_{2}\right)$ receptor rich ventral striatum. In general, open-label studies had a range of response from 53 to $74 \%$ of participants, although $65 \%$ of completers of the trial required rescue medication such as a second-generation antipsychotic or lithium. Double-blind studies did not show a superior range of response as compared with quetiapine. Furthermore, both Depakote and lithium were not found to be effective in the maintenance of bipolar disorder. Common side effects included sedation, gastrointestinal disturbance, headaches, dizziness, weight gain, tremor, and decrease platelet count. ${ }^{34}$

Padhy et al assessed the role of Depakote in conduct disorder and found that of reactive/adaptive/defensive/ impulsive aggression (RADI) $(n=68)$ showed a more favorable response to Depakote treatment than those with the subtype characterized by predatory/instrumental/premeditated aggression. ${ }^{35}$ As RADI is displayed commonly in the 
conduct disorder population, Depakote is likely to have a role in the treatment without gender or environmental bias. ${ }^{35}$

\section{Second-Generation AEDs}

\section{Clobazam}

Clobazam is a long-acting benzodiazepine acting on $\mathrm{GABA}_{\mathrm{A}}$ receptors. It is available as an anxiolytic since the 1970s and received FDA approval as an adjunct for use in partial complex seizures associated with Lennox-Gastaut syndrome. ${ }^{36}$ It has not been used in pediatric bipolar and behavior disorders.

\section{Felbamate}

The proposed mechanism of felbamate is the inhibition of NMDA receptor-related sodium currents, the potentiation of GABAergic activity and the inhibition of voltage-gated sodium channels. ${ }^{37}$ It is FDA approved for partial seizures since 1992. There have been no studies for its use in mood or behavior disorder. ${ }^{38,39}$

\section{Gabapentin/Pregabalin}

Both gabapentin and pregabalin are structural analogues of GABA. As opposed to gabapentin that has shown no role as a mood stabilizing agent in several trials, pregabalin has shown some promise in the maintenance phase of bipolar disorder both as antimanic and antidepressant agent. $8,40,41$ The subjects included adults and older adolescents. Out of the total of 58 , at the end of 2 -month acute trial, $41 \%$ were considered as responders to adjunctive pregabalin. The participants were taking on an average of three additional psychotropic medications. Gabapentin has been involved in several lawsuits related to its off-label use and associated adverse consequences. $^{41}$

\section{Lamotrigine}

Putative mechanisms of action of lamotrigine include sodium channel blockade and having an additional antiglutaminergic action that is believed to block the completed kindled seizures. $^{42}$ Lamotrigine is FDA approved for its use in the maintenance treatment of bipolar disorder in $\geq 18$ years. It is more specifically indicated in bipolar disorder depressed type. Peruzzolo et al, in a recent review of open-label trials, in pediatric population found that lamotrigine was effective in depressive phase of bipolar disorder. Lamotrigine was also associated with improvement in depressive, ADHD, and psychotic symptoms. ${ }^{42,43}$ There was a $25 \%$ discontinuation rate in these trials mostly related to the dermatological side effects of lamotrigine. Lamotrigine is associated with a reduction of interleukin $1 \beta$ and interleukin 2 , as well, which purportedly relate to the inflammatory processes in the pathophysiology of neurological disorders and diseases. ${ }^{44}$ The significance of this finding is under investigation due to the newly discovered immunomodulatory role of GABA and other anticonvulsants, including primidone, carbamazepine, levetiracetam, valproate, topiramate, phenobarbital, and lithium affecting the cytokines system, as well. ${ }^{45,46}$ Öncü et al published a case series on the potential use of lamotrigine in ADHD comorbid with mood disorders. ${ }^{47}$

\section{Levetiracetam}

Levetiracetam block high voltage-activated calcium channels and is approved for partial seizures. ${ }^{39}$ There have been several negative trials for its use in bipolar disorder in both pediatric population and adults. ${ }^{48,49}$ Its negative behavioral effects are discussed in the next section.

\section{Oxcarbazepine}

The chemical structure and mechanisms of action are similar to carbamazepine. ${ }^{50}$ It blocks voltage-gated sodium channels. In the past decade, there have been several open-label and double-blind studies published in the literature showing no difference between oxcarbazepine and placebo in different phases of bipolar disorder such as manic, depressed, mixed, or maintenance. $^{51-53}$

\section{Tiagabine}

Tiagabine is a potent inhibitor of GABA uptake into neurons and glial cells. ${ }^{54}$ After its approval as an antiepileptic, it showed some promise in the treatment of bipolar disorder with severe anxiety, however, in the following decade, its efficacy in mood and behavior is inconclusive at best. ${ }^{38,55,56}$ There is no evidence for its use in pediatric mood and behavior disorders to date.

\section{Topiramate}

Topiramate is considered to be a unique anticonvulsant and exerts its antiepileptic effect by several mechanisms, including modification of sodium and/or calcium-dependent action potentials, enhancement of GABA activity, and inhibition of kainate (KA)-mediated conductance at glutamate receptors of the KA type. ${ }^{54}$ There have been used in several trials of topiramate in pediatric mood disorders. ${ }^{38,54,57}$ The exact mechanism of weight loss with topiramate is unclear, but this side effect has successfully been used in a recent open-label trial. Topiramate was used as an adjunct with olanzapine in pediatric bipolar disorder to counter the side effect of weight gain. ${ }^{58}$ The weight gain in the olanzapine group was $5.3 \pm 2.1 \mathrm{~kg}$ and the weight gain in the olanzapine + topiramate group was statistically significantly lower, $2.6 \pm 3.6 \mathrm{~kg}$. Topiramate augmentation, however, did not lead to a greater reduction in symptoms of mania. ${ }^{58}$

\section{Stiripentol}

Stiripentol is a GABA modulator. ${ }^{59}$ There are no current pediatric mood and behavior disorder trials. ${ }^{38}$

\section{Vigabatrin}

Vigabatrin is the only selective, irreversible GABA-transaminase (GABA-T) inhibitor that greatly increases whole-brain levels of GABA, presumably making it more available to its receptor site. ${ }^{54}$ Vigabatrin use in pediatric mood disorders is not recommended due to potential adverse effect. Details are given in the next section.

\section{Zonisamide}

Zonisamide is a novel AED that has a broad combination of complementary mechanisms of action. It alters the fast 
inactivation threshold of voltage-dependent sodium channels and also inhibits low-threshold T-type calcium channels in neurons. ${ }^{60}$ Like topiramate, it is also shown to decrease appetite and increase weight loss. ${ }^{60}$ No double-blind randomized controlled trial (RCT) is available for its use in bipolar depression. ${ }^{38}$ The serious psychiatric adverse such as mania, psychosis, and suicidal ideation associated with zonisamide are discussed later. ${ }^{61}$

\section{Third-Generation AEDs}

Brivaracetam, Eslicarbazepine Acetate, Lacosamide, Retigabine, and Rufinamide

Third-generation AEDs have novel mechanisms of action. No pediatric psychiatric uses have been published as of yet. Due to its relationship with carbamazepine and oxcarbazepine, eslicarbazepine acetate was used in a recent trial of double-blind bipolar disorder in adults. The outcome was not statistically significant from placebo in treating manic symptoms. ${ }^{62}$

- Table 3 summarizes the AEDs effect on comorbid psychiatric disorders.

\section{Psychiatric Adverse Effects of AEDs}

\section{First-Generation AEDs}

\section{Barbiturates}

Phenobarbital and primidone have been long associated with behavioral and affective adverse effects, particularly depression. ${ }^{63}$ In an open-label study, adverse effects occurred in $61 \%$ (60/99) of children receiving primidone, most commonly irritability, sleep disturbance, and hyperactivity. Severe hyperactivity has been associated with phenobarbital leading to discontinuation. ${ }^{64-68}$ Rates of depression were elevated in two trials comparing phenobarbital to carbamazepine (40 vs. $4 \%$, and 38 vs. $0 \%$, respectively). ${ }^{69,70}$ In the former study, suicidal ideation was also more prevalent (47 vs. $4 \%$ ). In contrast, other studies have found no significant behavioral differences between phenobarbital compared with phenytoin, and carbamazepine. ${ }^{71,72}$

\section{Phenytoin}

Phenytoin has demonstrated favorable mood and behavioral adverse effect profiles in comparison to other antiepileptic medications; this underlies its continued choice as a starting first-generation medication. Four studies comparing phenytoin to phenobarbital found significantly lower rates of depression and behavioral adverse effects with phenytoin. ${ }^{63,69,73-76}$ In a double-blind RCT of children receiving phenytoin, clobazam, or carbamazepine, phenytoin was associated with fewer behavioral effects than clobazam. ${ }^{77}$ Though a long-term follow-up study of 392 children, demonstrated that phenytoin was associated with depression, ${ }^{73}$ phenytoin has rarely been associated with adverse mood effects. ${ }^{8}$ It should be noted that phenytoin toxicity can cause delirium, agitated psychosis, visual hallucinations, mania, and a syndrome consisting of lethargy, ataxia, ophthalmoplegia, involuntary movements, and paradoxical seizures. ${ }^{78-81}$

\section{Valproate (Divalproex)}

The beneficial affective and behavioral effects of valproate are utilized for treatment of numerous divergent psychiatric diagnoses in children and adolescents, as well as its continued emphasis in the treatment of epilepsy. Despite its known positive effects when treating seizures, the use of valproate in pediatric epilepsy has been linked to adverse cognitive effects, minor behavioral effects, and severe adverse psychiatric symptoms. ${ }^{72,82-85}$ A double-blind, RCT of 453 children comparing ethosuximide, valproic acid, and lamotrigine determined that the valproic acid cohort, $42 \%$ of the 115 subjects, experienced a high rate of adverse events, often leading to drug discontinuation. ${ }^{86}$ Hyperactivity, attention problems, hostility, decreased concentration, personality change, and sleep problems were reported more frequently in the valproic acid group. In addition, a significant number of subjects in the valproic acid cohort experienced negative effects on attentional measures, in contrast to ethosuximide or lamotrigine cohort. Valproate demonstrated a more favorable behavioral symptom profile when compared with phenobarbital and had fewer adverse effects in comparison to phenytoin, or carbamazepine. ${ }^{67,72,87}$

Table 3 AEDs effect on comorbid psychiatric disorders

\begin{tabular}{|c|c|c|c|c|c|c|c|}
\hline \multicolumn{2}{|l|}{$\begin{array}{l}\text { Mood lability/bipolar } \\
\text { disorder }\end{array}$} & \multicolumn{2}{|l|}{ Anxiety } & \multicolumn{2}{|l|}{ Depression } & \multicolumn{2}{|l|}{ Psychosis } \\
\hline Consider & Avoid & Consider & Avoid & Consider & Avoid & Consider & Avoid \\
\hline $\begin{array}{l}\text { Carbamazepine } \\
\text { Oxcarbazepine } \\
\text { Phenytoin Valproate } \\
\text { Lamotrigine }\end{array}$ & & $\begin{array}{l}\text { Benzodiazepines } \\
\text { Gabapentin } \\
\text { Pregabalin }\end{array}$ & $\begin{array}{l}\text { Felbamate } \\
\text { Lamotrigine } \\
\text { Levetiracetam } \\
\text { Tiagabine }\end{array}$ & Lamotrigine & $\begin{array}{l}\text { Barbiturates } \\
\text { Levetiracetam } \\
\text { Pregabalin } \\
\text { Tiagabine } \\
\text { Topiramate } \\
\text { Vigabatrin } \\
\text { Zonisamide }\end{array}$ & & $\begin{array}{l}\text { Ethosuximide } \\
\text { Felbamate } \\
\text { Levetiracetam } \\
\text { Phenytoin } \\
\text { Tiagabine } \\
\text { Topiramate } \\
\text { Vigabatrin } \\
\text { Zonisamide }\end{array}$ \\
\hline
\end{tabular}

Abbreviation: AEDs, antiepileptic drugs.

Source: Adapted from Zaccara and Perucca. ${ }^{13}$ 


\section{Carbamazepine}

The affective, behavioral, and cognitive profile of carbamazepine has been extensively examined, as described above. Overall, psychiatric adverse effects are not common in children and adults treated with carbamazepine. ${ }^{24,76,88}$ Behavioral changes described in 7/200 children with diverse seizure types included irritability, developmental regression, agitation, obsessive thinking, auditory hallucinations, delirium, psychosis, combativeness, being "spaced out," insomnia, aggression, hyperactivity, and paranoia. The same study reported hallucinations or psychosis in one patient and delirium in a second patient. ${ }^{89}$ In an RCT of 108 children treated with carbamazepine, 6 of 54 children developed restlessness and hyperactivity, though behavioral improvement in young children has also been reported. ${ }^{30}$ In comparisons to topiramate, phenobarbital, primidone, and phenytoin, carbamazepine demonstrated less adverse psychiatric effects, including more favorable attention and motor performance, and less behavioral problems, anxiety, depression, and aggression. ${ }^{72,73,75,86,89}$ However, when compared with vigabatrin, clobazam, and valproate, carbamazepine was more likely to elicit sleep disturbance, cognitive, and mood and behavioral adverse effects. ${ }^{73,90,91}$ One double-blind study in partial epilepsy reported evidence of agitation (6\%), depression (3\%), and insomnia (2\%), whereas a controlled study in generalized epilepsy found no evidence of increased depression, aggression, or neurosis with treatment. ${ }^{92,93}$ The use of carbamazepine has been linked to improvements in obsessive compulsive and paranoid symptom profiles, and has demonstrated both positive and negative effects on cognitive performance in patients with Rolandic epilepsy. ${ }^{94,95}$

\section{Ethosuximide}

Ethosuximide is relatively well tolerated by pediatric epilepsy patients with few psychiatric adverse effects. A double-blind RCT of 453 children comparing ethosuximide, valproic acid, and lamotrigine determined a higher rate of adverse events (42\% of the 115 subjects), in the valproic acid cohort, unlike the subjects in the ethosuximide cohort. ${ }^{63,96}$ Transient, mild attentional problems were demonstrated in children treated with ethosuximide when compared with baseline. ${ }^{97,98}$ "Forced normalization" resulting in psychosis has been reported in both children and adults treated with ethosuximide. ${ }^{79,99}$ Case reports also describe the onset of psychosis, mania, suicidal ideation, "autism, anxiety, and weeping fits" in children and adolescents with ethosuximide initiation. ${ }^{79,100}$

- Table 4 summarizes the first-generation AEDs and their pertinent adverse effects.

\section{Second-Generation AEDs}

\section{Clobazam}

The FDA approved clobazam as an adjunctive treatment for Lennox-Gastaut syndrome in adults and children 2 years of age and older in 2011, though it was originally synthesized in the 1970 s as an anxiolytic. Data regarding efficacy and tolerability of Clobazam is available due to longstanding international clinical use. In a multicenter, double-blinded RCT of 235 children, aged 2 to 16 years, clobazam was associated with an increased likelihood of adverse psychiatric effects in comparison to carbamazepine and phenytoin. ${ }^{77}$ Conversely, in another randomized double-blind trial, Bawden et al demonstrated no difference in

Table 4 Psychiatric adverse effects of first generation AEDs

\begin{tabular}{|c|c|c|c|c|}
\hline \multirow[t]{2}{*}{ AEDs } & \multicolumn{3}{|l|}{ Effects } & \multirow[t]{2}{*}{ Comments } \\
\hline & Mood & Behavior & Cognition & \\
\hline $\begin{array}{l}\text { Barbiturates } \\
\text { (Phenobarbital } \\
\text { and Primidone) }\end{array}$ & $\begin{array}{l}\text { Depression } \\
\text { Irritability } \\
\text { Suicidal Ideation } \\
\text { Self -injurious } \\
\text { behavior }\end{array}$ & $\begin{array}{l}\text { Hyperactivity } \\
\text { Aggression } \\
\text { Agitation } \\
\text { Sleep disturbance }\end{array}$ & $\begin{array}{l}\text { Impaired cognition } \\
\text { Inattention }\end{array}$ & $\begin{array}{l}\text { May be more common in children, } \\
\text { patients with intellectual disability }\end{array}$ \\
\hline Carbamazepine & $\begin{array}{l}\text { Irritability } \\
\text { Depression } \\
\text { Psychosis }\end{array}$ & $\begin{array}{l}\text { Agitation } \\
\text { Aggression } \\
\text { Sleep disturbance } \\
\text { Somnolence } \\
\text { Hyperactivity } \\
\text { Behavioral disturbance }\end{array}$ & Impaired attention & $\begin{array}{l}\text { Generally uncommon } \\
\text { Less AE compared with topiramate, } \\
\text { more compared with vigabatrin, } \\
\text { valproate } \\
\text { Improvement in OCD and paranoia }\end{array}$ \\
\hline Ethosuximide & $\begin{array}{l}\text { Anxiety } \\
\text { Psychosis } \\
\text { Mania }\end{array}$ & & Mild attention & Few psychiatric AE \\
\hline Phenytoin & $\begin{array}{l}\text { Depression } \\
\text { Irritability } \\
\text { Psychosis }\end{array}$ & Somnolence & $\begin{array}{l}\text { Mild cognitive } \\
\text { impairment }\end{array}$ & $\begin{array}{l}\text { Toxicity associated with agitated, } \\
\text { psychosis, mania, visual } \\
\text { hallucinations }\end{array}$ \\
\hline $\begin{array}{l}\text { Valproate } \\
\text { (Divalproex) }\end{array}$ & $\begin{array}{l}\text { Irritability } \\
\text { Mood lability }\end{array}$ & $\begin{array}{l}\text { Hyperactivity } \\
\text { Aggression } \\
\text { Behavioral disturbance } \\
\text { Hostility } \\
\text { Somnolence } \\
\text { Sleep problems }\end{array}$ & $\begin{array}{l}\text { Attention problems } \\
\text { Decreased concentration } \\
\text { Improved alertness }\end{array}$ & $\begin{array}{l}\text { Conflicting data on cognitive } \\
\text { and mood effects }\end{array}$ \\
\hline
\end{tabular}

Abbreviations: AE, aeromedical evacuation; AEDs, antiepileptic drugs. 
psychiatric effects between clobazam and carbamazepine, at 6-week and 12-month follow-up. ${ }^{101}$ Severe behavioral adverse effects have been associated with clobazam. These symptoms include severe aggression, and severe depression associated with suicidal ideation, self-injurious behavior, incessant motor activity, and aggressive agitation, in developmentally delayed and developmentally disabled pediatric patients with epilepsy. Notably, the behavioral dysregulation occurred within a short period of clobazam initiation, and remitted within 3 weeks of discontinuation of the medication. ${ }^{102,103}$ Despite these behavioral effects, clobazam is considered among the safest AEDs for the children. $^{104}$

\section{Felbamate}

Felbamate has been associated with both beneficial and adverse psychiatric effects in epilepsy patients, though data in children are limited. Positive cognitive outcomes include improvements in alertness, attention, concentration, as well as in social, intellectual, and motor functioning. ${ }^{105,106}$ However, in one retrospective study of 38 children, nearly a quarter of patients experienced psychiatric adverse effects, including insomnia, anorexia, irritability, and motor or vocal tics. One patient's vocal and motor tics were severe and disruptive, and prompted discontinuation therapy. ${ }^{107}$ During an RCT evaluating felbamate monotherapy, 6 of the 21 treated patients discontinued felbamate due to treatment-emergent psychiatric adverse effects, including psychosis, anxiety, sleeping difficulties, abdominal discomfort, and orobuccal dyskinesia. ${ }^{108}$ Felbamate has also been linked to milder adverse effects such as decreased appetite, insomnia, and fatigue. ${ }^{109-111}$

\section{Gabapentin}

Gabapentin has been associated with behavioral dysregulation, though this is most commonly seen in children and adolescents with intellectual disability or developmental delay. ${ }^{105,112-115}$ Reported psychiatric adverse effects typically include hyperactivity, irritability, and agitation or aggression. Risk factors increasing the likelihood of behavioral symptoms include a history of ADHD, learning disorder, or previous behavior disorder and are reversible.

\section{Lamotrigine}

Lamotrigine is generally well tolerated both as an adjunctive medication and as monotherapy in children and adolescents. ${ }^{116,117}$ Two open-label studies in children and adolescent reported limited occurrence of overall adverse effects, including psychiatric effects. Hyperactivity, agitation, aggression, self-injurious behaviors, violence, insomnia, and hallucinations have also been reported. ${ }^{118}$ In contrast, another open-label study demonstrated improved behavior and alertness in $33 \%$ of children and adolescents using lamotrigine as adjunctive therapy. ${ }^{119}$ Two RCTs demonstrated the increased occurrence of behavioral changes, aggression, depression, anxiety, agitation, and confusion in adults with epilepsy, ${ }^{120}$ and case reports describe potential exacerbation of behavioral problems in intellectually disabled patients. ${ }^{121}$ The positive effects of lamotrigine on cognitive function in pediatric and adult epilepsy patients include improved alertness, attention, and learning. ${ }^{122-125}$

\section{Levetiracetam}

Levetiracetam has well-established negative and positive behavioral and affective adverse effects in both pediatric and adult epilepsy patients. The most common adverse effects in children and adults with partial or mixed epilepsy are irritability, somnolence, aggression, and hyperactivity. ${ }^{112}$ Behavioral and emotional adverse effects are common, occurring in 5 to $34 \%$ of children and adolescents taking levetiracetam. ${ }^{126-130}$ A small study of children found irritability in nearly half of the sample, followed by somnolence, irritability, and aggression. ${ }^{131}$ A recent case report details the onset of obsessive-compulsive symptoms after initiation of levetiracetam in an adolescent with no psychiatric history or intellectual disability, with resolution of the symptoms after discontinuation. ${ }^{132}$ Another case report details a reversible autistic regressive episode in a biologically vulnerable young girl, which resolved after the discontinuation of levetiracetam. ${ }^{133}$ When used in young children, nearly $16 \%$ of the patients in one trial discontinued levetiracetam due to behavioral effects. ${ }^{134}$ While there may be an elevated risk of adverse psychiatric symptoms in patients with intellectual disabilities with prior behavior problems, psychiatric history, or history of status epilepticus, improved alertness and behavior in patients with learning disabilities has also been described. ${ }^{135,136}$ The use of levetiracetam was linked to improvements in cognition and/or behavior in children with partial epilepsy. ${ }^{137,138}$ A RCT of children with partial epilepsy demonstrated positive effects on activities and competence scores on the child-behavior checklist scale. ${ }^{139}$

\section{Oxcarbazepine}

Unlike its analog, carbamazepine, oxcarbazepine has demonstrated few psychiatric adverse effects. Among the limited studies performed on the pediatric population with partial epilepsy, one blinded, randomized, study of infants and young children with partial seizures and another unblended (open label), RCT of patients demonstrated mild somnolence as the most frequent behavioral adverse effect. ${ }^{120,140}$ Aggression has been linked to oxcarbazepine monotherapy in a small number of children. ${ }^{141}$

Oxcarbazepine demonstrated mild beneficial effects on cognitive function in a pediatric retrospective study. ${ }^{142}$ In a prospective, multicenter, open-label trial of 168 children with partial epilepsy, oxcarbazepine monotherapy demonstrated improvements in perceptual organization, attention and concentration, and picture completion subtests after treatment in the intellectually normal group. The same study indicated improvement of the social problem parameter in intellectually impaired children. ${ }^{143}$ Oxcarbazepine was not associated with decreased cognitive function when compared with carbamazepine and valproate. ${ }^{144}$

\section{Pregabalin}

Few adverse mood or behavior effects have been associated with pregabalin treatment. ${ }^{145}$ In one open-label add-on trial of children and adolescents, behavioral changes were reported by $32 \%$ of patients. ${ }^{146}$ Adults treated with pregabalin in an open trial reported some memory difficulties, but no 
mood symptoms. In this trial, patients with partial epilepsy treated with pregabalin demonstrated higher anxiety and variability in hostility scores than those treated with levetiracetam. Overactivation leading to discontinuation has also been reported. ${ }^{42}$

\section{Stiripentol}

Stiripentol is not currently FDA approved in the United States. Stiripentol has been linked to adverse behavioral effects, such as hyperactivity, irritability, aggressiveness, and insomnia. In a randomized, double-blind, placebo-controlled trial, drowsiness, hyperactivity, aggressiveness, and insomnia were reported in $91 \%$ of the patients taking stiripentol versus $25 \%$ of those on placebo. ${ }^{147}$

\section{Tiagabine}

There are conflicting data regarding the psychotropic profile of tiagabine. In a recent study of 231 adults and children with diverse seizure types, psychiatric adverse effects included psychomotor slowing (13\%), ataxia (8\%), and insomnia (5\%). The majority (12/19) of the serious adverse effects reported were behavioral. ${ }^{148}$ An earlier study examining tiagabine in children with epilepsy determined that the psychiatric adverse effects in children were reported in $83 \%$ of the children studied, and paralleled those of their adult counterparts, namely, asthenia, nervousness, dizziness, and somnolence. ${ }^{149}$ While five clinical trials have found a greater incidence of mood disorders and nervousness in patients taking tiagabine compared with those who received placebo, ${ }^{150}$ several case series and open-label studies have found that tiagabine may have beneficial or no effects on mood and anxiety. $^{151-153}$

\section{Topiramate}

Though generally well tolerated, topiramate has been associated with a wide range of mood, behavior, and cognitive side effects in children and adults with epilepsy. Two RCTs of children treated with topiramate reported depression, anxiety/agitation, and aggression as the most common psychiatric adverse effects, especially in patients with partial epilepsy. Other frequent adverse effects include cognitive slowing, dysphasia, and agitation, memory effects, anxiety, appetite changes, somnolence, and poor concentration. ${ }^{87,154,155}$ The cognitive effects of topiramate are well studied in both adults and children; however, data on the nature and duration of topiramate effects are divergent. Persistence of mild-to-moderate cognitive or behavioral impairment has been reported at 6-, 12-month, and long-term follow-up. ${ }^{89,156}$ However, positive behavioral and cognitive effects and increased alertness in children have also been reported. ${ }^{157-159}$ A doubleblind RCT of topiramate monotherapy in children found highdose topiramate was associated with slowing in psychomotor reaction times, though learning, memory, and executive function were not affected. ${ }^{160}$ A retrospective, cross-sectional study found use of topiramate increased the risk of cognitive impairment by the factor 1.3 to 2.0 and negatively affected executive function. ${ }^{161}$

\section{Vigabatrin}

Psychiatric adverse effects of vigabatrin in children and adults are well described, both beneficial and detrimental. ${ }^{162,163}$ The most common behavioral presentations include hyperkinesia or hyperactivity, irritability, aggression, agitation, and insomnia, and rarely severe aggressive agitation. ${ }^{78}$ Reported risk factors for developing adverse psychiatric effects during vigabatrin therapy include high starting and maintenance doses, severe form of epilepsy, and psychiatric history-though other studies refute the association of psychiatric adverse effects with psychiatric history. ${ }^{164-166}$ Though more common in adults, a case report describes the occurrence of psychosis in an adolescent with the use of vigabatrin, with a potential occurrence of "forced normalization." 167 Severe psychiatric adverse effects requiring psychiatric hospitalization has been described. ${ }^{168}$ Vigabatrin has fewer psychiatric effects when compared with lamotrigine and gabapentin. ${ }^{169}$ The beneficial effects of vigabatrin on psychiatric symptoms include improved mood and alertness in children with partial epilepsy, ${ }^{162}$ and some reduction in aggression and stereotypies. ${ }^{170}$ One outlying study reported cognitive impairments in children with vigabatrin treatment. ${ }^{171}$

\section{Zonisamide}

Zonisamide has been subject to discontinuation due to adverse mood and behavior effects. In a single-center study of 544 patients, $6.9 \%$ discontinued therapy due to adverse psychiatric effects, most commonly depression, aggression, psychosis, and irritability. ${ }^{172}$ A retrospective chart review of adults and adolescents treated with zonisamide reported incidence of aggression, agitation, irritability, poor attention, and hyperactivity in $23.5 \%$ of the patients. ${ }^{173}$ Diverging from these findings, a double-blind RCT in adults and adolescents reported no discontinuation of zonisamide due to adverse effects, but noted evidence of somnolence, anorexia, and ataxia. ${ }^{174}$ Two retrospective studies of adult and pediatric patients found low rates of psychiatric adverse effects. ${ }^{175,176}$

- Table 5 summarizes the second-generation AEDs and their pertinent adverse effects.

\section{Third-Generation AEDs}

\section{Brivaracetam}

Limited data are available regarding the safety and tolerability of brivaracetam. In one RCT, the most common reason for discontinuation was psychiatric adverse effects, unrelated to dose. Though the study found elevated rates of behavioral adverse events such as irritability and aggression, the numbers reported appeared to be less than in prior published reports of levetiracetam. ${ }^{177}$ Clinical trials evaluating the use of brivaracetam in pediatric populations are ongoing. ${ }^{178}$

\section{Eslicarbazepine Acetate}

Cognitive and psychiatric side effects associated with eslicarbazepine acetate have occasionally included anxiety, depression, insomnia, and irritability. However, in a 1-year followup of adults enrolled in clinical trials of eslicarbazepine, mood or cognitive effects were not reported. ${ }^{179}$ Limited data are 
Effects of AEDs on Pediatric Cognition, Mood, and Behavior Afzal et al. 11

Table 5 Psychiatric adverse effects of second generation AEDs

\begin{tabular}{|c|c|c|c|c|}
\hline \multirow[t]{2}{*}{ AEDs } & \multicolumn{3}{|l|}{ Effects } & \multirow[t]{2}{*}{ Comments } \\
\hline & Mood & Behavior & Cognition & \\
\hline Clobazam & $\begin{array}{l}\text { Depression } \\
\text { Irritability } \\
\text { Suicidal ideation } \\
\text { Self-injury }\end{array}$ & $\begin{array}{l}\text { Hyperactivity } \\
\text { Aggression } \\
\text { Agitation }\end{array}$ & & $\begin{array}{l}\text { May be more common in } \\
\text { children, patients with } \\
\text { intellectual disability }\end{array}$ \\
\hline Felbamate & $\begin{array}{l}\text { Irritability } \\
\text { Anxiety } \\
\text { Psychosis }\end{array}$ & $\begin{array}{l}\text { Sleep disturbance } \\
\text { Orobuccal dyskinesia }\end{array}$ & $\begin{array}{l}\text { Improved in alertness, attention, } \\
\text { concentration, social functioning }\end{array}$ & $\begin{array}{l}\text { Both beneficial and detrimental } \\
\text { effects }\end{array}$ \\
\hline Gabapentin & $\begin{array}{l}\text { Irritability } \\
\text { Mood lability } \\
\text { Anxiety } \\
\text { Depression }\end{array}$ & $\begin{array}{l}\text { Aggression } \\
\text { Hyperactivity } \\
\text { Somnolence }\end{array}$ & Confusion & $\begin{array}{l}\text { More common in patients with } \\
\text { developmental delay, ADHD }\end{array}$ \\
\hline Oxcarbazepine & & $\begin{array}{l}\text { Aggression } \\
\text { Somnolence }\end{array}$ & $\begin{array}{l}\text { Improved attention and } \\
\text { concentration } \\
\text { Improved social problem } \\
\text { parameter }\end{array}$ & $\begin{array}{l}\text { Few psychiatric AE } \\
\text { No "forced normalization" }\end{array}$ \\
\hline Pregabalin & Anxiety & $\begin{array}{l}\text { Hyperactivity } \\
\text { Somnolence } \\
\text { Behavioral } \\
\text { disturbance }\end{array}$ & Memory impairment & Few psychiatric $\mathrm{AE}$ \\
\hline Lamotrigine & $\begin{array}{l}\text { Self-injury } \\
\text { Anxiety } \\
\text { Irritability } \\
\text { Psychosis }\end{array}$ & $\begin{array}{l}\text { Hyperactivity } \\
\text { Agitation } \\
\text { Aggression } \\
\text { Sleep disturbance } \\
\text { Somnolence }\end{array}$ & $\begin{array}{l}\text { Improved behavior, alertness, } \\
\text { attention, learning } \\
\text { Confusion }\end{array}$ & $\begin{array}{l}\text { May be more common in } \\
\text { patients with intellectual } \\
\text { disability }\end{array}$ \\
\hline Levetiracetam & $\begin{array}{l}\text { Irritability } \\
\text { Nervousness } \\
\text { Depression } \\
\text { Mood Lability } \\
\text { Anxiety } \\
\text { Psychosis } \\
\text { Improved mood }\end{array}$ & $\begin{array}{l}\text { Hyperactivity } \\
\text { Aggression } \\
\text { Behavioral } \\
\text { disturbance } \\
\text { Somnolence }\end{array}$ & $\begin{array}{l}\text { Improved cognition and behavior } \\
\text { Improvement on } \mathrm{CBCL}\end{array}$ & $\begin{array}{l}\text { Both beneficial and detrimental } \\
\text { effects. } \\
\text { May be more common in } \\
\text { patients with intellectual } \\
\text { disability }\end{array}$ \\
\hline Stiripentol & Irritability & $\begin{array}{l}\text { Hyperactivity } \\
\text { Aggression } \\
\text { Sleep Disturbance }\end{array}$ & & \\
\hline Tiagabine & $\begin{array}{l}\text { Anxiety } \\
\text { Mood disturbance } \\
\text { Irritability } \\
\text { Depression }\end{array}$ & $\begin{array}{l}\text { Sleep disturbance } \\
\text { Orobuccal dyskinesia }\end{array}$ & Slowing & $\begin{array}{l}\text { Conflicting data. } \\
\text { Serious behavioral effects } \\
\text { reported }\end{array}$ \\
\hline Topiramate & $\begin{array}{l}\text { Depression } \\
\text { Nervousness } \\
\text { Anxiety } \\
\text { Psychosis } \\
\text { Irritability } \\
\text { Mood lability }\end{array}$ & $\begin{array}{l}\text { Aggression } \\
\text { Agitation Behavioral } \\
\text { disturbance } \\
\text { Somnolence }\end{array}$ & $\begin{array}{l}\text { Cognitive impairment of } \\
\text { attention and memory } \\
\text { Word finding difficulty } \\
\text { Psychomotor reaction slowing } \\
\text { Inattention } \\
\text { Confusion } \\
\text { Somnolence }\end{array}$ & \\
\hline Vigabatrin & $\begin{array}{l}\text { Irritability } \\
\text { Depression } \\
\text { Psychosis }\end{array}$ & $\begin{array}{l}\text { Hyperactivity } \\
\text { Aggression } \\
\text { Agitation } \\
\text { Sleep disturbance } \\
\text { Behavioral disturbance }\end{array}$ & Improved alertness & $\begin{array}{l}\text { Both beneficial and detrimental } \\
\text { effects. } \\
\text { AE more common with initiation, } \\
\text { severe epilepsy }\end{array}$ \\
\hline Zonisamide & $\begin{array}{l}\text { Depression } \\
\text { Irritability Psychosis }\end{array}$ & $\begin{array}{l}\text { Hyperactivity } \\
\text { Aggression } \\
\text { Agitation } \\
\text { Somnolence }\end{array}$ & Inattention & Wide range of $\mathrm{AE}$ \\
\hline
\end{tabular}

Abbreviations: $\mathrm{AE}$, aeromedical evacuation; $\mathrm{ADHD}$, attention-deficit/hyperactivity disorder; $\mathrm{CBCL}$, child-behavior checklist. 
available regarding mood, behavioral, or cognitive effects of eslicarbazepine acetate in children, though in one open-label study of 31 children two patients developed moderate psychomotor agitation and behavioral adverse effects. ${ }^{180}$

\section{Ezogabine/Retigabine}

Retigabine, known as ezogabine in the United States, has demonstrated some neuropsychiatric adverse effects in clinical trials. Elevated rates of confusion, psychosis, and auditory and visual hallucinations were reported in three pivotal doubleblinded, RCTs of greater than 1,200 patients, though less than $5 \%$ of the studied population was affected..$^{3,181,182}$ The factors conferring greater risk of neuropsychiatric symptoms included dosage, initial exposure to the medication, and rapid titration. Other dose-related symptoms in adults included dizziness and somnolence. ${ }^{8}$ The adverse effects were generally mild or moderate in severity, mostly emerged during initial titration phase, and diminished with continued use. ${ }^{183}$

\section{Lacosamide}

In a prospective open-label study of adjunctive lacosamide for 70 children with refractory epilepsy, 50.6\% (40/70) experienced psychiatric adverse effects, most commonly drowsiness, hyperactivity, sleep disturbance, and giddiness. Most adverse effects observed were mild-to-moderate in severity, though one patient withdrew due to aggressive behavior. ${ }^{184}$ In a separate case report, the authors describe severe hyperactivity, aggression, and inattention within 1 week of initiating lacosamide, which abated on discontinuation. ${ }^{185}$ In a retrospective study of 16 children treated with lacosamide as adjunctive therapy, Guilhoto et al reported that one patient developed oral tics while a second developed depression associated with suicidal ideation. Both patients' symptoms subsided after lacosamide was withdrawn. A third patient developed behavioral outbursts causing discontinuation of lacosamide treatment. ${ }^{186}$ Lacosamide use in children has been associated with the irritability and personality change. ${ }^{187-189}$ Dizziness, headache, ataxia, motor incoordination, and visual disturbances were commonly described in pediatric studies and case series. ${ }^{190-192}$ The cognitive effects of lacosamide in children have not been described.

\section{Perampanel}

In a multicenter, double-blind, randomized, placebo-controlled trial of 388 adults and adolescents dizziness (38\%), somnolence (18\%), and irritability (7.5\%) were the most common psychiatric adverse effects. ${ }^{193}$ A pooled analysis of phase III data from 1,478 patients indicated that dose-related psychiatric and behavioral effects were observed at a greater rate in the perampanel groups compared with the placebo group. Significant psychiatric adverse effects affected 12 patients (1.2\%) receiving perampanel, including three cases of aggression and one case of suicidal ideation. $^{194}$ Serious psychiatric and behavioral adverse events were also reported in other studies of perampanel. ${ }^{195}$

\section{Rufinamide}

Rufinamide is generally well tolerated by children. Both a pooled analysis of seven studies (including 212 rufinamide treated and 197 placebo-treated children) examining the safety and tolerability of rufinamide, and a double-blind, RCT of rufinamide in pediatric patients with Lennox-Gastaut syndrome did not find an association with psychiatric adverse effects. ${ }^{196-198}$ However, adverse psychiatric effects with rufinamide have been described. In a prospective, open-label study of pediatric patients $(n=70)$ with focal refractory epilepsy found, $5.7 \%$ of patients reported agitation and irritability, leading to rufinamide discontinuation. ${ }^{199}$ Adverse side effects mainly occurred during the initial titration. In a similar study of children and young adults with Lennox-Gastaut syndrome the most common side effects (6/70 patients) were somnolence and aggressive behavior, though these were transient and mild. ${ }^{200}$ In a retrospective, open-label study reviewing use of rufinamide in 40 children less than 4 years of age, adverse effects occurred in $37.5 \%$ of the children and were most commonly vomiting, drowsiness, irritability, and anorexia. ${ }^{201}$ In two patients with psychiatric history, rufinamide use was linked to suicidal ideation. ${ }^{202}$ Neurocognitive side effects associated with rufinamide include irritability, shift in mood, sleep disturbance, and attentional disturbances. ${ }^{203}$ Overall, rufinamide appears to have a favorable cognitive profile compared with other AEDs. ${ }^{201}$ Clinical observation and parent report indicated positive behavioral effects, including improved attention, school performance, and social interaction in children taking rufinamide. ${ }^{203}$ A divergent finding was reported in a study examining cognitive effects of rufinamide in adolescents and adults, where no significant difference was noted between the pre- and posttreatment formal cognitive assessments. ${ }^{204}$

- Table 6 summarizes the third-generation AEDs and their pertinent adverse effects.

\section{AEDs and Suicide}

Since the FDA issued an alert about an increased risk of suicide ideation and suicide behavior in people treated with AEDs in 2008, several retrospective cohort and case-control studies have attempted to clarify this issue, but gathered results have been contradictory. One retrospective analysis indicates that a subgroup of people with epilepsy, rather than specific mechanism of action of the drug, confers greater risk of developing psychiatric adverse effects of antiepileptic medications. $^{202}$ Another analysis revealed that the data are not supportive of the presence of a "class effect" on suiciderelated behavior; on the contrary there are some data suggesting such an effect concerning treatment with topiramate, lamotrigine, and levetiracetam for which further research is needed. ${ }^{203}$ One study initially indicated elevated risk of suicidal behavior with phenobarbital, primidone, phenytoin, lamotrigine, but increased risk diminished or disappeared when psychiatric comorbidity and other well established risk factors for suicidality were analyzed. ${ }^{204}$ An observational nested case-control study including 453 patients with epilepsy displaying self-harm or suicidal behavior reported AEDs identified as having a high frequency of causing depression, levetiracetam, tiagabine, topiramate, vigabatrin, may increase risk of self-harm or suicidal 
Table 6 Psychiatric adverse effects of third-generation AEDs

\begin{tabular}{|c|c|c|c|c|}
\hline \multirow[t]{2}{*}{ AEDs } & \multicolumn{3}{|l|}{ Effects } & \multirow[t]{2}{*}{ Comments } \\
\hline & Mood & Behavior & Cognition & \\
\hline Brivaracetam & Irritability & Aggression & & \\
\hline Eslicarbazepine acetate & $\begin{array}{l}\text { Anxiety, } \\
\text { depression }\end{array}$ & $\begin{array}{l}\text { Insomnia } \\
\text { Irritability }\end{array}$ & $\begin{array}{l}\text { Psychomotor agita- } \\
\text { tion and aggression }\end{array}$ & \\
\hline Lacosamide & $\begin{array}{l}\text { Depression } \\
\text { Personality } \\
\text { change Irritability } \\
\text { Nervousness }\end{array}$ & $\begin{array}{l}\text { Hyperactivity } \\
\text { Sleep disturbance } \\
\text { Somnolence } \\
\text { Aggression } \\
\text { Orobuccal tics } \\
\text { Behavioral disturbance }\end{array}$ & Inattention & \\
\hline Perampanel & $\begin{array}{l}\text { Irritability } \\
\text { Suicidal ideation }\end{array}$ & Aggression Somnolence & & \\
\hline Retigabine/ezogabine & Psychosis & Somnolence & $\begin{array}{l}\text { Confusion } \\
\text { Cognitive } \\
\text { impairment }\end{array}$ & \\
\hline Rufinamide & Irritability & $\begin{array}{l}\text { Somnolence } \\
\text { Agitation } \\
\text { Behavioral disturbance } \\
\text { Aggression }\end{array}$ & & $\begin{array}{l}\text { Common reason for } \\
\text { discontinuation }\end{array}$ \\
\hline
\end{tabular}

Abbreviation: AEDs, antiepileptic drugs.

behavior. ${ }^{205}$ Although some AEDs can be associated with treatment-emergent psychiatric problems that can lead to suicidal ideation and behavior, the actual suicidal risk is yet to be established, but it seems to be very low. ${ }^{202}$ Given the FDA's warning regarding the potential connection between suicidal behavior and epilepsy medications, elevated suicidal risk in the pediatric population with chronic illness, comorbidity of epilepsy and psychopathology, ${ }^{206-208}$ the paucity of data investigating the relationship between AEDs and suicidality in children, further investigation is warranted to clarify the actual potential risk of suicidality with use of AEDs in children and adolescents. Close monitoring and screening of selfinjurious behavior and suicidal ideation is recommended, especially in the presence of comorbid psychiatric disorders. ${ }^{12,209,210}$

\section{Summary and Recommendations}

An increased availability of second- and third-generation AEDs for refractory seizures in the past three decades has not translated into a significantly better seizure control in the big picture. As with the older generation AEDs (benzodiazepines, carbamazepine, phenobarbital, phenytoin, ethosuximide, valproate), newer AEDs (clobazam, felbamate, gabapentin/pregabalin, oxcarbazepine, lamotrigine, levetiracetam, stiripentol, tiagabine, topiramate, vigabatrin, zonisamide, brivaracetam, eslicarbazepine, lacosamide, perampanel, retigabine, rufinamide) are associated with mood and behavior effects including mood irritability, anxiety, depression, psychosis, and even suicidal ideation. The bidirectional relationship of epilepsy with psychiatric conditions such as mood, anxiety, psychosis, ADHD, dis- ruptive behavior disorders, and suicidal ideation is well established ${ }^{12}$ and cautions clinicians to monitor for these side effects, as the long-term safety profile of newer AEDs is still emerging in pediatric population. Authors suggest the following: (1) baseline psychiatric assessment of all epileptic patients with the use of standardized tools, (2) referral for neuropsychological evaluation in case of refractory seizures to establish cognitive function profile and periodic follow-ups to monitor progression, (3) in addition to the medication management, interdisciplinary approach to the care of patients including psychosocial interventions such as family psychoeducational and supportive interventions, individual therapy, and school accommodations, (4) early recognition of evolving safety concerns such as suicidal ideation or aggression, behavioral dyscontrol, mood dysregulation, and cognitive effects, and (5) prompt referral to psychiatry services for further assessment and possible psychopharmacological interventions.

In conclusion, the jury is still out to establish the long-term safety profile of newer AEDs. A multidisciplinary coordinated team approach that includes neurologists, mental health professionals, and school-based services is warranted to provide the current evidence-based care to the pediatric population suffering from this highly complex neurobiological condition. Collaboration between the child psychiatrist, the clinicians treating the child's medical concerns, and a neuropsychologist, to monitor behavioral and cognitive impact, is well advised. This will allow for identification of potential challenges, and promote appropriate referrals and accommodation planning, to support the child in developing more effectively toward best management of mood and behavior symptoms, and educational goals. 


\section{References}

1 Wolf P. History of epilepsy: nosological concepts and classification. Epileptic Disord 2014;16(3):261-269

2 Chaudhary UJ, Duncan JS, Lemieux L. A dialogue with historical concepts of epilepsy from the Babylonians to Hughlings Jackson: persistent beliefs. Epilepsy Behav 2011;21(2):109-114

3 Brodie MJ. Antiepileptic drug therapy the story so far. Seizure 2010;19(10):650-655

4 Clouston TS. Experiments to determine the precise effect of bromide of potassium in epilepsy. Br J Psychiatry 1868;14(67): 305-321

5 The Diagnostic and Statistical Manual of Mental Disorders. 5th ed. Washington, DC: American Psychiatric Association; 2013

6 U.S. Food and Drug Administration (FDA). Available at: http:// www.fda.gov/drugs/drugsafety/informationbydrugclass/default. htm. Accessed January 8, 2016

7 Haymarket Media, Inc. Mood disorders. Available at: http://www. empr.com/mood-disorders/category/17/0/. Accessed January 7 , 2016

8 Perucca P, Mula M. Antiepileptic drug effects on mood and behavior: molecular targets. Epilepsy Behav 2013;26(3): 440-449

9 LaRoche SM. A new look at the second-generation antiepileptic drugs: a decade of experience. Neurologist 2007;13(3):133-139

10 Potschka H. Pharmacological treatment strategies: Mechanisms of antiepileptic drugs. Epileptology 2013;1(1):31-37

11 Brodie MJ, Covanis A, Gil-Nagel A, et al. Antiepileptic drug therapy: does mechanism of action matter? Epilepsy Behav 2011;21(4):331-341

12 Afzal KI, Drossos T, Hunter S. Mood and behavior disorder in pediatric epilepsy-A review of literature. J Pediatr Epilepsy 2013; 2(3):157-172

13 Zaccara G, Perucca E. Interactions between antiepileptic drugs, and between antiepileptic drugs and other drugs. Epileptic Disord 2014;16(4):409-431

14 Tran AR, Zito JM, Safer DJ, Hundley SD. National trends in pediatric use of anticonvulsants. Psychiatr Serv 2012;63(11): 1095-1101

15 American Psychiatric Association. Diagnostic and Statistical Manual of Mental Disorders: DSM-IV-TR. Washington, DC: American Psychiatric Association; 2000

16 Italiano D, Capuano A, Alibrandi A, et al. Indications of newer and older anti-epileptic drug use: findings from a southern Italian general practice setting from 2005-2011. Br J Clin Pharmacol 2015;79(6):1010-1019

17 Drug safety update. Off-label or unlicensed use of medicines: prescribers' responsibilities. Available at: http://www.mhra.gov. uk/Safetyinformation/DrugSafetyUpdate/CON087990. Accessed January 24, 2016

18 "Off-label" and investigational use of marketed drugs, biologics, and medical devices-information sheet. Available at: http:// www.fda.gov/RegulatoryInformation/Guidances/ucm126486. htm. Accessed March 14, 2016

19 Stafford RS. Regulating off-label drug use-rethinking the role of the FDA. N Engl J Med 2008;358(14):1427-1429

20 Wittich CM, Burkle CM, Lanier WL. Ten common questions (and their answers) about off-label drug use. Mayo Clin Proc 2012; 87(10):982-990

21 Leslie DL, Mohamed S, Rosenheck RA. Off-label use of antipsychotic medications in the department of Veterans Affairs health care system. Psychiatr Serv 2009;60(9):1175-1181

22 Zito JM, Derivan AT, Kratochvil CJ, Safer DJ, Fegert JM, Greenhill LL. Off-label psychopharmacologic prescribing for children: history supports close clinical monitoring. Child Adolesc Psychiatry Ment Health 2008;2(1):24. Doi: 10.1186/1753-2000-2-24

23 Kwan P, Brodie MJ. Phenobarbital for the treatment of epilepsy in the 21st century: a critical review. Epilepsia 2004;45(9): $1141-1149$
24 Findling RL, Ginsberg LD. The safety and effectiveness of openlabel extended-release carbamazepine in the treatment of children and adolescents with bipolar I disorder suffering from a manic or mixed episode. Neuropsychiatr Dis Treat 2014; 10:1589-1597

25 Schneider MR, Klein CC, Weber W, et al. The effects of carbamazepine on prefrontal activation in manic youth with bipolar disorder. Psychiatry Res 2014;223(3):268-270

26 Leucht S, Helfer B, Dold M, Kissling W, McGrath J. Carbamazepine for schizophrenia. Cochrane Database Syst Rev 2014;5:CD001258. Doi: 10.1002/14651858.CD001258.pub2

27 Vajda FJ, Eadie MJ. The clinical pharmacology of traditional antiepileptic drugs. Epileptic Disord 2014;16(4):395-408

28 Bersudsky Y. Phenytoin: an anti-bipolar anticonvulsant? Int J Neuropsychopharmacol 2006;9(4):479-484

29 Gallagher P, Reid KS, Watson S. Phenytoin, an anti-bipolar anticonvulsant: a potential anti-glucocorticoid mechanism? Int J Neuropsychopharmacol 2006;9(5):627-628

30 Sitges M, Chiu LM, Reed RC. Effects of Levetiracetam, Carbamazepine, Phenytoin, Valproate, Lamotrigine, Oxcarbazepine, Topiramate, Vinpocetine and Sertraline on Presynaptic Hippocampal Na $(+)$ and $\mathrm{Ca}(2+)$ Channels Permeability. Neurochem Res 2016; 41(4):758-769

31 Masuch A, Shieh CH, van Rooijen N, van Calker D, Biber K. Mechanism of microglia neuroprotection: Involvement of P2 $\times$ 7, TNF $\alpha$, and valproic acid. Glia 2016;64(1):76-89

32 Liu HY, Potter MP, Woodworth KY, et al. Pharmacologic treatments for pediatric bipolar disorder: a review and meta-analysis. J Am Acad Child Adolesc Psychiatry 2011;50(8):749-762.e39

33 Pavuluri MN. Pharmacologic treatments for pediatric bipolar disorder. J Am Acad Child Adolesc Psychiatry 2011;50(12): 1290, author reply 1290-1291. Doi: 10.1016/j.jaac.2011.09.002

34 Pavuluri MN, Passarotti AM, Fitzgerald JM, Wegbreit E, Sweeney JA. Risperidone and divalproex differentially engage the frontostriato-temporal circuitry in pediatric mania: a pharmacological functional magnetic resonance imaging study. J Am Acad Child Adolesc Psychiatry 2012;51(2):157-170.e5

35 Padhy R, Saxena K, Remsing L, Huemer J, Plattner B, Steiner H. Symptomatic response to divalproex in subtypes of conduct disorder. Child Psychiatry Hum Dev 2011;42(5):584-593

36 Sankar R. GABA(A) receptor physiology and its relationship to the mechanism of action of the 1,5-benzodiazepine clobazam. CNS Drugs 2012;26(3):229-244

37 Shi LL, Dong J, Ni H, Geng J, Wu T. Felbamate as an add-on therapy for refractory epilepsy. Cochrane Database Syst Rev 2014;7: CD008295. Doi: 10.1002/14651858.CD008295.pub3

38 Reinares M, Rosa AR, Franco C, et al. A systematic review on the role of anticonvulsants in the treatment of acute bipolar depression. Int J Neuropsychopharmacol 2013;16(2):485-496

39 Bialer M. Chemical properties of antiepileptic drugs (AEDs). Adv Drug Deliv Rev 2012;64(10):887-895

40 Fullerton CA, Busch AB, Frank RG. The rise and fall of gabapentin for bipolar disorder: a case study on off-label pharmaceutical diffusion. Med Care 2010;48(4):372-379

41 Chace MJ, Zhang F, Fullerton CA, Huskamp HA, Gilden D, Soumerai SB. Intended and unintended consequences of the gabapentin off-label marketing lawsuit among patients with bipolar disorder. J Clin Psychiatry 2012;73(11):1388-1394

42 Schaffer LC, Schaffer CB, Miller AR, Manley JL, Piekut JA, Nordahl TE. An open trial of pregabalin as an acute and maintenance adjunctive treatment for outpatients with treatment resistant bipolar disorder. J Affect Disord 2013;147(1-3):407-410

43 Ketter TA, Manji HK, Post RM. Potential mechanisms of action of lamotrigine in the treatment of bipolar disorders. J Clin Psychopharmacol 2003;23(5):484-495

44 Peruzzolo TL, Tramontina S, Rohde LA, Zeni CP. Pharmacotherapy of bipolar disorder in children and adolescents: an update. Rev Bras Psiquiatr 2013;35(4):393-405 
45 Himmerich $\mathrm{H}$, Bartsch S, Hamer $\mathrm{H}$, et al. Impact of mood stabilizers and antiepileptic drugs on cytokine production invitro. J Psychiatr Res 2013;47(11):1751-1759

46 Munkholm K, Braüner JV, Kessing LV, Vinberg M. Cytokines in bipolar disorder vs. healthy control subjects: a systematic review and meta-analysis. J Psychiatr Res 2013;47(9):1119-1133

47 Öncü B, Er O, Çolak B, Nutt DJ. Lamotrigine for attention deficithyperactivity disorder comorbid with mood disorders: a case series. J Psychopharmacol 2014;28(3):282-283

48 Cerullo MA, Strakowski SM. A systematic review of the evidence for the treatment of acute depression in bipolar I disorder. CNS Spectr 2013;18(4):199-208

49 Saricicek A, Maloney K, Muralidharan A, et al. Levetiracetam in the management of bipolar depression: a randomized, doubleblind, placebo-controlled trial. J Clin Psychiatry 2011;72(6): 744-750

50 Ambrósio AF, Soares-Da-Silva P, Carvalho CM, Carvalho AP. Mechanisms of action of carbamazepine and its derivatives, oxcarbazepine, BIA 2-093, and BIA 2-024. Neurochem Res 2002;27(1-2):121-130

51 Macmillan CM, Gonzalez-Heydrich JM. Oxcarbazepine is no more effective than placebo for reducing manic symptoms of bipolar I disorder in children and adolescents. Evid Based Ment Health 2007;10(2):59. Doi: 10.1136/ebmh.10.2.59

52 Wagner KD, Kowatch RA, Emslie GJ, et al. A double-blind, randomized, placebo-controlled trial of oxcarbazepine in the treatment of bipolar disorder in children and adolescents. Am J Psychiatry 2006;163(7):1179-1186

53 Vasudev A, Macritchie K, Vasudev K, Watson S, Geddes J, Young AH. Oxcarbazepine for acute affective episodes in bipolar disorder. Cochrane Database Syst Rev 2011;(12):CD004857. Doi: 10.1002/14651858.CD004857.pub2

54 Angehagen M, Ben-Menachem E, Rönnbäck L, Hansson E. Novel mechanisms of action of three antiepileptic drugs, vigabatrin, tiagabine, and topiramate. Neurochem Res 2003;28(2):333-340

55 Hertzman M. Tiagabine for treatment of bipolar disorder with severe anxiety. Psychiatry (Edgmont) 2005;2(5):11-11

56 Vasudev A, Macritchie K, Rao SK, Geddes J, Young AH. Tiagabine for acute affective episodes in bipolar disorder. Cochrane Database Syst Rev 2012;12:CD004694. Doi: 10.1002/14651858.CD004694.pub3

57 Correll CU, Sheridan EM, DelBello MP. Antipsychotic and mood stabilizer efficacy and tolerability in pediatric and adult patients with bipolar I mania: a comparative analysis of acute, randomized, placebo-controlled trials. Bipolar Disord 2010;12(2): 116-141

58 Wozniak J, Mick E, Waxmonsky J, Kotarski M, Hantsoo L, Biederman J. Comparison of open-label, 8-week trials of olanzapine monotherapy and topiramate augmentation of olanzapine for the treatment of pediatric bipolar disorder. J Child Adolesc Psychopharmacol 2009;19(5):539-545

59 Greenfield LJ Jr. Molecular mechanisms of antiseizure drug activity at GABAA receptors. Seizure 2013;22(8):589-600

60 Biton V. Clinical pharmacology and mechanism of action of zonisamide. Clin Neuropharmacol 2007;30(4):230-240

61 Haw C, Stubbs J. A survey of the off-label use of mood stabilizers in a large psychiatric hospital. J Psychopharmacol 2005;19(4):402-407

62 Glauser TA. Behavioral and psychiatric adverse events associated with antiepileptic drugs commonly used in pediatric patients. J Child Neurol 2004;19(Suppl 1):S25-S38

63 Wolf SM, Carr A, Davis DC, et al. The value of phenobarbital in the child who has had a single febrile seizure: a controlled prospective study. Pediatrics 1977;59(3):378-385

64 Knudsen FU, Vestermark S. Prophylactic diazepam or phenobarbitone in febrile convulsions: a prospective, controlled study. Arch Dis Child 1978;53(8):660-663

65 Domizio S, Verrotti A, Ramenghi LA, Sabatino G, Morgese G. Antiepileptic therapy and behaviour disturbances in children. Childs Nerv Syst 1993;9(5):272-274
66 Herranz JL, Armijo JA, Arteaga R. Effectiveness and toxicity of phenobarbital, primidone, and sodium valproate in the prevention of febrile convulsions, controlled by plasma levels. Epilepsia 1984;25(1):89-95

67 Vining EP, Mellitis ED, Dorsen MM, et al. Psychologic and behavioral effects of antiepileptic drugs in children: a double-blind comparison between phenobarbital and valproic acid. Pediatrics 1987;80(2):165-174

68 Brent DA, Crumrine PK, Varma R, Brown RV, Allan MJ. Phenobarbital treatment and major depressive disorder in children with epilepsy: a naturalistic follow-up. Pediatrics 1990;85(6): 1086-1091

69 Brent DA, Crumrine PK, Varma RR, Allan M, Allman C. Phenobarbital treatment and major depressive disorder in children with epilepsy. Pediatrics 1987;80(6):909-917

70 Pal DK. Phenobarbital for childhood epilepsy: systematic review. Paediatr Perinat Drug Ther 2006;7(1):31-42

71 Banu SH, Jahan M, Koli UK, Ferdousi S, Khan NZ, Neville B. Side effects of phenobarbital and carbamazepine in childhood epilepsy: randomised controlled trial. BMJ 2007;334(7605):1207. Doi: $10.1136 /$ bmj.39022.436389.BE

72 Herranz JL, Armijo JA, Arteaga R. Clinical side effects of phenobarbital, primidone, phenytoin, carbamazepine, and valproate during monotherapy in children. Epilepsia 1988;29(6):794-804

73 Thilothammal N, Banu K, Ratnam RS. Comparison of phenobarbitone, phenytoin with sodium valproate: randomized, doubleblind study. Indian Pediatr 1996;33(7):549-555

74 de Silva M, MacArdle B, McGowan M, et al. Randomised comparative monotherapy trial of phenobarbitone, phenytoin, carbamazepine, or sodium valproate for newly diagnosed childhood epilepsy. Lancet 1996;347(9003):709-713

75 Smith DB, Mattson RH, Cramer JA, Collins JF, Novelly RA, Craft B. Results of a nationwide Veterans Administration Cooperative Study comparing the efficacy and toxicity of carbamazepine, phenobarbital, phenytoin, and primidone. Epilepsia 1987;28 (Suppl 3):S50-S58

76 Heller AJ, Chesterman P, Elwes RD, et al. Phenobarbitone, phenytoin, carbamazepine, or sodium valproate for newly diagnosed adult epilepsy: a randomised comparative monotherapy trial. J Neurol Neurosurg Psychiatry 1995;58(1):44-50

77 Canadian Study Group for Childhood Epilepsy. Clobazam has equivalent efficacy to carbamazepine and phenytoin as monotherapy for childhood epilepsy. Epilepsia 1998;39(9):952-959

78 McLellan DL, Swash M. Choreo-athetosis and encephalopathy induced by phenytoin. BMJ 1974;2(5912):204-205

79 Chua HC, Venketasubramanian N, Tan CB, Tjia H. Paradoxical seizures in phenytoin toxicity. Singapore Med J 1999;40(4): 276-277

80 Schmitz B. Psychiatric syndromes related to antiepileptic drugs. Epilepsia 1999;40(Suppl 10):S65-S70

81 Marín LL, García-Peñas JJ, Herguedas JL, et al. Phenytoin-induced visual disturbances mimicking Delirium Tremens in a child. Eur J Paediatr Neurol 2010;14(5):460-463

82 Meador KJ, Loring DW, Hulihan JF, Kamin M, Karim R; CAPSS-027 Study Group. Differential cognitive and behavioral effects of topiramate and valproate. Neurology 2003;60(9):1483-1488

83 Sherard ES Jr, Steiman GS, Couri D. Treatment of childhood epilepsy with valproic acid: results of the first 100 patients in a 6-month trial. Neurology 1980;30(1):31-35

84 Coulter DL, Wu H, Allen RJ. Valproic acid therapy in childhood epilepsy. JAMA 1980;244(8):785-788

85 Berg I, Butler A, Ellis M, Foster J. Psychiatric aspects of epilepsy in childhood treated with carbamazepine, phenytoin or sodium valproate: a random trial. Dev Med Child Neurol 1993;35(2): 149-157

86 Glauser TA, Cnaan A, Shinnar S, et al; Childhood Absence Epilepsy Study Team. Ethosuximide, valproic acid, and lamotrigine in 
childhood absence epilepsy: initial monotherapy outcomes at 12 months. Epilepsia 2013;54(1):141-155

87 Marson AG, Al-Kharusi AM, Alwaidh M, et al; SANAD Study group. The SANAD study of effectiveness of valproate, lamotrigine, or topiramate for generalised and unclassifiable epilepsy: an unblinded randomised controlled trial. Lancet 2007;369(9566): 1016-1026

88 Silverstein FS, Parrish MA, Johnston MV. Adverse behavioral reactions in children treated with carbamazepine (Tegretol). J Pediatr 1982;101(5):785-787

89 Kang HC, Eun BL, Lee CW, et al; Korean Pediatric Topiramate Study Group. The effects on cognitive function and behavioral problems of topiramate compared to carbamazepine as monotherapy for children with benign rolandic epilepsy. Epilepsia 2007;48(9):1716-1723

90 Kälviäinen R, Aikiä M, Saukkonen AM, Mervaala E, Riekkinen PJ Sr. Vigabatrin vs carbamazepine monotherapy in patients with newly diagnosed epilepsy. A randomized, controlled study. Arch Neurol 1995;52(10):989-996

91 Zamponi N, Cardinali C. Open comparative long-term study of vigabatrin vs carbamazepine in newly diagnosed partial seizures in children. Arch Neurol 1999;56(5):605-607

92 Chadwick D; Vigabatrin European Monotherapy Study Group. Safety and efficacy of vigabatrin and carbamazepine in newly diagnosed epilepsy: a multicentre randomised double-blind study. Lancet 1999;354(9172):13-19

93 Shehata GA, Bateh Ael-A, Hamed SA, Rageh TA, Elsorogy YB. Neuropsychological effects of antiepileptic drugs (carbamazepine versus valproate) in adult males with epilepsy. Neuropsychiatr Dis Treat 2009;5:527-533

94 Lee SA, Lee HW, Heo K, et al. Cognitive and behavioral effects of lamotrigine and carbamazepine monotherapy in patients with newly diagnosed or untreated partial epilepsy. Seizure 2011; 20(1):49-54

95 Seidel WT, Mitchell WG. Cognitive and behavioral effects of carbamazepine in children: data from benign rolandic epilepsy. J Child Neurol 1999;14(11):716-723

96 Glauser TA, Cnaan A, Shinnar S, et al; Childhood Absence Epilepsy Study Group. Ethosuximide, valproic acid, and lamotrigine in childhood absence epilepsy. N Engl J Med 2010; 362(9):790-799

97 Mandelbaum DE, Burack GD, Bhise VV. Impact of antiepileptic drugs on cognition, behavior, and motor skills in children with new-onset, idiopathic epilepsy. Epilepsy Behav 2009;16(2):341-344

98 Ijff DM, Aldenkamp AP. Cognitive side-effects of antiepileptic drugs in children. Handb Clin Neurol 2013;111:707-718

99 Wolf P. The clinical syndromes of forced normalisation. Folia Psychiatr Neurol Jpn 1984;38:187-192

100 Chien J. Ethosuximide-induced mania in a 10 -year-old boy. Epilepsy Behav 2011;21(4):483-485

101 Bawden HN, Camfield CS, Camfield PR, et al; Canadian Study Group for Childhood Epilepsy. The cognitive and behavioural effects of clobazam and standard monotherapy are comparable. Epilepsy Res 1999;33(2-3):133-143

102 Sheth RD, Ronen GM, Goulden KJ, Penney S, Bodensteiner JB. Clobazam for intractable pediatric epilepsy. J Child Neurol 1995; 10(3):205-208

103 Sheth RD, Goulden KJ, Ronen GM. Aggression in children treated with clobazam for epilepsy. Clin Neuropharmacol 1994;17(4): 332-337

104 Chu-Shore CJ, Thiele EA. New drugs for pediatric epilepsy. Semin Pediatr Neurol 2010;17(4):214-223

105 Ketter TA, Post RM, Theodore WH. Positive and negative psychiatric effects of antiepileptic drugs in patients with seizure disorders. Neurology 1999;53(5, Suppl 2):S53-S67

106 Gay PE, Mecham GF, Coskey JS, Sadler T, Thompson JA. Behavioral effects of felbamate in childhood epileptic encephalop- athy (Lennox-Gastaut syndrome). Psychol Rep 1995;77 (3 Pt 2):1208-1210

107 Zupanc ML, Roell Werner R, Schwabe MS, et al. Efficacy of felbamate in the treatment of intractable pediatric epilepsy. Pediatr Neurol 2010;42(6):396-403

108 Theodore WH, Albert P, Stertz B, et al. Felbamate monotherapy: implications for antiepileptic drug development. Epilepsia 1995; 36(11):1105-1110

109 Heyman E, Levin N, Lahat E, Epstein O, Gandelman-Marton R. Efficacy and safety of felbamate in children with refractory epilepsy. Eur J Paediatr Neurol 2014;18(6):658-662

110 Pellock JM, Faught E, Leppik IE, Shinnar S, Zupanc ML. Felbamate: consensus of current clinical experience. Epilepsy Res 2006; 71(2-3):89-101

111 Bourgeois BF. Felbamate. Semin Pediatr Neurol 1997;4(1):3-8

112 Eddy CM, Rickards HE, Cavanna AE. Behavioral adverse effects of antiepileptic drugs in epilepsy. J Clin Psychopharmacol 2012; 32(3):362-375

113 Mikati MA, Choueri R, Khurana DS, Riviello J, Helmers S, Holmes G. Gabapentin in the treatment of refractory partial epilepsy in children with intellectual disability. J Intellect Disabil Res 1998; 42(Suppl 1):57-62

114 Morris GL. Gabapentin. Epilepsia 1999;40(Suppl 5):S63-S70

115 Lee DO, Steingard RJ, Cesena M, Helmers SL, Riviello JJ, Mikati MA. Behavioral side effects of gabapentin in children. Epilepsia 1996; 37(1):87-90

116 Besag FM, Dulac O, Alving J, Mullens EL. Long-term safety and efficacy of lamotrigine (Lamictal) in paediatric patients with epilepsy. Seizure 1997;6(1):51-56

117 Eriksson AS, Nergårdh A, Hoppu K. The efficacy of lamotrigine in children and adolescents with refractory generalized epilepsy: a randomized, double-blind, crossover study. Epilepsia 1998; 39(5):495-501

118 Cardenas JF, Rho JM, Ng YT. Reversible lamotrigine-induced neurobehavioral disturbances in children with epilepsy. J Child Neurol 2010;25(2):182-187

119 McKee JR, Sunder TR, FineSmith R, et al. Lamotrigine as adjunctive therapy in patients with refractory epilepsy and mental retardation. Epilepsy Behav 2003;4(4):386-394

120 Marson AG, Al-Kharusi AM, Alwaidh M, et al; SANAD Study group. The SANAD study of effectiveness of carbamazepine, gabapentin, lamotrigine, oxcarbazepine, or topiramate for treatment of partial epilepsy: an unblinded randomised controlled trial. Lancet 2007;369(9566):1000-1015

121 Beran RG, Gibson RJ. Aggressive behaviour in intellectually challenged patients with epilepsy treated with lamotrigine. Epilepsia 1998;39(3):280-282

122 Barron TF, Hunt SL, Hoban TF, Price ML. Lamotrigine monotherapy in children. Pediatr Neurol 2000;23(2):160-163

123 Vigneswari G, Sofiah A, Hussain IH. Lamotrigine as an add-on therapy in intractable paediatric epilepsy-the Kuala Lumpur Hospital experience. Med J Malaysia 2001;56(3):359-364

124 Brodbeck V, Jansen V, Fietzek U, Muehe C, Weber G, Heinen F. Long-term profile of lamotrigine in 119 children with epilepsy. Eur J Paediatr Neurol 2006;10(3):135-141

125 Pressler RM, Binnie CD, Coleshill SG, Chorley GA, Robinson RO. Effect of lamotrigine on cognition in children with epilepsy. Neurology 2006;66(10):1495-1499

126 Khurana DS, Kothare SV, Valencia I, Melvin JJ, Legido A. Levetiracetam monotherapy in children with epilepsy. Pediatr Neurol 2007;36(4):227-230

127 Giroux PC, Salas-Prato M, Théorêt Y, Carmant L. Levetiracetam in children with refractory epilepsy: lack of correlation between plasma concentration and efficacy. Seizure 2009;18(8):559-563

128 Krief P, Li Kan, Maytal J. Efficacy of levetiracetam in children with epilepsy younger than 2 years of age. J Child Neurol 2008;23(5): 582-584 
129 Obeid M, Pong AW. Efficacy and tolerability of high oral doses of levetiracetam in children with epilepsy. Epilepsy Res 2010;91(1): 101-105

130 Peake D, Mordekar S, Gosalakkal J, et al. Retention rate of levetiracetam in children with intractable epilepsy at 1 year. Seizure 2007;16(2):185-189

131 Callenbach PM, Arts WF, ten Houten R, et al. Add-on levetiracetam in children and adolescents with refractory epilepsy: results of an open-label multi-centre study. Eur J Paediatr Neurol 2008; 12(4):321-327

132 Fujikawa M, Kishimoto Y, Kakisaka Y, et al. Obsessive-compulsive behavior induced by levetiracetam. J Child Neurol 2015;30(7): 942-944

133 Camacho A, Espín JC, Nuñez N, Simón R. Levetiracetam-induced reversible autistic regression. Pediatr Neurol 2012;47(1):65-67

134 Perry MS, Benatar M. Efficacy and tolerability of levetiracetam in children younger than 4 years: a retrospective review. Epilepsia 2007;48(6):1123-1127

135 Helmstaedter C, Witt JA. The effects of levetiracetam on cognition: a non-interventional surveillance study. Epilepsy Behav 2008;13(4):642-649

136 Ben-Menachem E, Gilland E. Efficacy and tolerability of levetiracetam during 1-year follow-up in patients with refractory epilepsy. Seizure 2003;12(3):131-135

137 Levisohn PM, Mintz M, Hunter SJ, Yang H, Jones J; N01103 Levetiracetam Study Group. Neurocognitive effects of adjunctive levetiracetam in children with partial-onset seizures: a randomized, double-blind, placebo-controlled, noninferiority trial. Epilepsia 2009;50(11):2377-2389

138 Lagae L, Buyse G, Ceulemans B. Clinical experience with levetiracetam in childhood epilepsy: an add-on and mono-therapy trial. Seizure 2005;14(1):66-71

139 de la Loge C, Hunter SJ, Schiemann J, Yang H. Assessment of behavioral and emotional functioning using standardized instruments in children and adolescents with partial-onset seizures treated with adjunctive levetiracetam in a randomized, placebocontrolled trial. Epilepsy Behav 2010;18(3):291-298

140 Piña-Garza JE, Espinoza R, Nordli D, et al. Oxcarbazepine adjunctive therapy in infants and young children with partial seizures. Neurology 2005;65(9):1370-1375

141 Kothare SV, Khurana DS, Mostofi N, et al. Oxcarbazepine monotherapy in children and adolescents: a single-center clinical experience. Pediatr Neurol 2006;35(4):235-239

142 Seo JG, Lee DI, Hwang YH, et al. Comparison of cognitive effects of lamotrigine and oxcarbazepine in epilepsy patients. J Clin Neurol 2007;3(1):31-37

143 Eun SH, Eun BL, Lee JS, et al. Effects of lamotrigine on cognition and behavior compared to carbamazepine as monotherapy for children with partial epilepsy. Brain Dev 2012;34(10):818-823

144 Donati F, Gobbi G, Campistol J, et al; Oxcarbazepine Cognitive Study Group. Effects of oxcarbazepine on cognitive function in children and adolescents with partial seizures. Neurology 2006; 67(4):679-682

145 Zaccara G, Gangemi P, Perucca P, Specchio L. The adverse event profile of pregabalin: a systematic review and meta-analysis of randomized controlled trials. Epilepsia 2011;52(4):826-836

146 Ciesielski AS, Samson S, Steinhoff BJ. Neuropsychological and psychiatric impact of add-on titration of pregabalin versus levetiracetam: a comparative short-term study. Epilepsy Behav 2006;9(3):424-431

147 Chiron C, Marchand MC, Tran A, et al. Stiripentol in severe myoclonic epilepsy in infancy: a randomised placebo-controlled syndrome-dedicated trial. STICLO study group. Lancet 2000; 356(9242):1638-1642

148 Vossler DG, Morris GL III, Harden CL, et al; Postmarketing Antiepileptic Drug Survey (PADS) group study investigators. Tiagabine in clinical practice: effects on seizure control and behavior. Epilepsy Behav 2013;28(2):211-216
149 Pellock JM. Tiagabine (gabitril) experience in children. Epilepsia 2001;42(Suppl 3):49-51

150 Leppik IE. Tiagabine: the safety landscape. Epilepsia 1995;36 (Suppl 6):S10-S13

151 Dodrill CB, Arnett JL, Shu V, Pixton GC, Lenz GT, Sommerville KW. Effects of tiagabine monotherapy on abilities, adjustment, and mood. Epilepsia 1998;39(1):33-42

152 Suppes T, Chisholm KA, Dhavale D, et al. Tiagabine in treatment refractory bipolar disorder: a clinical case series. Bipolar Disord 2002;4(5):283-289

153 Rosenthal M. Tiagabine for the treatment of generalized anxiety disorder: a randomized, open-label, clinical trial with paroxetine as a positive control. J Clin Psychiatry 2003; 64(10):1245-1249

154 Kerr MP, Baker GA, Brodie MJ. A randomized, double-blind, placebo-controlled trial of topiramate in adults with epilepsy and intellectual disability: impact on seizures, severity, and quality of life. Epilepsy Behav 2005;7(3):472-480

155 Yeung S, Ferrie CD, Murdoch-Eaton DG, Livingston JH. Topiramate for drug-resistant epilepsies. Eur J Paediatr Neurol 2000;4(1): 31-33

156 Coppola G, Verrotti A, Resicato G, et al. Topiramate in children and adolescents with epilepsy and mental retardation: a prospective study on behavior and cognitive effects. Epilepsy Behav 2008; 12(2):253-256

157 Moreland EC, Griesemer DA, Holden KR. Topiramate for intractable childhood epilepsy. Seizure 1999;8(1):38-40

158 Martin P, Schreiner A, Rettig K, Schäuble B. Topiramate in patients with epilepsy and intellectual disability. Epilepsy Behav 2009; 14(3):496-502

159 Brandl U, Kurlemann G, Neubauer B, Rettig K, Schäuble B, Schreiner A. Seizure and cognitive outcomes in children and adolescents with epilepsy treated with topiramate. Neuropediatrics 2010;41(3):113-120

160 Pandina GJ, Ness S, Polverejan E, et al. Cognitive effects of topiramate in migraine patients aged 12 through 17 years. Pediatr Neurol 2010;42(3):187-195

161 Witt JA, Elger CE, Helmstaedter C. Impaired verbal fluency under topiramate-evidence for synergistic negative effects of epilepsy, topiramate, and polytherapy. Eur J Neurol 2013;20(1): 130-137

162 Camposano SE, Major P, Halpern E, Thiele EA. Vigabatrin in the treatment of childhood epilepsy: a retrospective chart review of efficacy and safety profile. Epilepsia 2008;49(7):1186-1191

163 Kluger G, Berz K, Holthausen $\mathrm{H}$. The long-term use of vigabatrin and lamotrigine in patients with severe childhood onset epilepsy. Eur J Paediatr Neurol 2001;5(1):37-40

164 Ferrie CD, Robinson RO, Panayiotopoulos CP. Psychotic and severe behavioural reactions with vigabatrin: a review. Acta Neurol Scand 1996;93(1):1-8

165 Thomas L, Trimble M, Schmitz B, Ring H. Vigabatrin and behaviour disorders: a retrospective survey. Epilepsy Res 1996;25(1): 21-27

166 Wong IC. Retrospective study of vigabatrin and psychiatric behavioural disturbances. Epilepsy Res 1995;21(3):227-230

167 Weber P, Dill P, Datta AN. Vigabatrin-induced forced normalization and psychosis-prolongated termination of behavioral symptoms but persistent antiepileptic effect after withdrawal. Epilepsy Behav 2012;24(1):138-140

168 Guberman A, Bruni J; The Canadian Vigabatrin Study Group. Long-term open multicentre, add-on trial of vigabatrin in adult resistant partial epilepsy. Seizure 2000;9(2):112-118

169 Bhaumik S, Branford D, Duggirala C, Ismail IA. A naturalistic study of the use of vigabatrin, lamotrigine and gabapentin in adults with learning disabilities. Seizure 1997;6(2):127-133

170 Veggiotti P, De Agostini G, Muzio C, et al. Vigabatrin use in psychotic epileptic patients: report of a prospective pilot study. Acta Neurol Scand 1999;99(3):142-146 
171 Gaily E, Appelqvist K, Kantola-Sorsa E, et al. Cognitive deficits after cryptogenic infantile spasms with benign seizure evolution. Dev Med Child Neurol 1999;41(10):660-664

172 White JR, Walczak TS, Marino SE, Beniak TE, Leppik IE, Birnbaum AK. Zonisamide discontinuation due to psychiatric and cognitive adverse events: a case-control study. Neurology 2010;75(6):513-518

$173 \mathrm{Kim}$ HL, Aldridge J, Rho JM. Clinical experience with zonisamide monotherapy and adjunctive therapy in children with epilepsy at a tertiary care referral center. J Child Neurol 2005;20(3):212-219

174 Faught E, Ayala R, Montouris GG, Leppik IE; Zonisamide 922 Trial Group. Randomized controlled trial of zonisamide for the treatment of refractory partial-onset seizures. Neurology 2001; 57(10):1774-1779

175 Cavanna AE, Seri S. Psychiatric adverse effects of zonisamide in patients with epilepsy and mental disorder comorbidities. Epilepsy Behav 2013;29(2):281-284

176 Thampratankul L, Khongkhatithum C, Visudtibhan A. Efficacy and safety of zonisamide in Thai children and adolescents with intractable seizures. J Child Neurol 2015;30(4):527-531

177 Pack AM. Brivaracetam, a Novel Antiepileptic Drug: Is it Effective and Safe? Results from One Phase III Randomized Trial. Epilepsy Curr 2014;14(4):196-198

178 UCB BIOSCIENCES, Inc. Brivaracetam safety and efficacy follow-up study in subjects with epilepsy (BRITE ${ }^{\mathrm{TM}}$ ). Available at: https:// clinicaltrials.gov/ct2/show/NCT01339559. Accessed March 14, 2016

179 McCormack PL, Robinson DM. Eslicarbazepine acetate. CNS Drugs 2009;23(1):71-79

180 Almeida L, Minciu I, Nunes T, et al. Pharmacokinetics, efficacy, and tolerability of eslicarbazepine acetate in children and adolescents with epilepsy. J Clin Pharmacol 2008;48(8):966-977

181 Porter RJ, Partiot A, Sachdeo R, Nohria V, Alves WM; 205 Study Group. Randomized, multicenter, dose-ranging trial of retigabine for partial-onset seizures. Neurology 2007;68(15):1197-1204

182 French JA, Abou-Khalil BW, Leroy RF, et al; RESTORE 1/Study 301 Investigators. Randomized, double-blind, placebo-controlled trial of ezogabine (retigabine) in partial epilepsy. Neurology 2011; 76(18):1555-1563

183 Chhim RF, Shelton CM, Christensen ML. Recent new drug approvals, part 2: drugs undergoing active clinical studies in children. J Pediatr Pharmacol Ther 2013;18(1):14-38

184 Pasha I, Kamate M, Didagi SK. Efficacy and tolerability of lacosamide as an adjunctive therapy in children with refractory partial epilepsy. Pediatr Neurol 2014;51(4):509-514

185 Pasha I, Kamate M, Didagi SK. Reversible inattention and hyperactivity in a child on lacosamide - in south Indian subpopulation. IOSR. J Pharm Biol Sci. 2014;9:66-67

186 Guilhoto LM, Loddenkemper T, Gooty VD, et al. Experience with lacosamide in a series of children with drug-resistant focal epilepsy. Pediatr Neurol 2011;44(6):414-419

187 Gavatha M, Ioannou I, Papavasiliou AS. Efficacy and tolerability of oral lacosamide as adjunctive therapy in pediatric patients with pharmacoresistant focal epilepsy. Epilepsy Behav 2011;20(4): 691-693

188 Verrotti A, Loiacono G, Pizzolorusso A, et al. Lacosamide in pediatric and adult patients: comparison of efficacy and safety. Seizure 2013;22(3):210-216

189 Kim JS, Kim H, Lim BC, et al. Lacosamide as an adjunctive therapy in pediatric patients with refractory focal epilepsy. Brain Dev 2014;36(6):510-515

190 Heyman E, Lahat E, Levin N, Berkovitch M, Gandelman-Marton R. Preliminary efficacy and safety of lacosamide in children with refractory epilepsy. Eur J Paediatr Neurol 2012;16(1):15-19

191 Rastogi RG, Ng YT. Lacosamide in refractory mixed pediatric epilepsy: a prospective add-on study. J Child Neurol 2012;27; (4):492-495
192 Grosso S, Parisi P, Spalice A, Verrotti A, Balestri P. Efficacy and safety of lacosamide in infants and young children with refractory focal epilepsy. Eur J Paediatr Neurol 2014;18; (1):55-59

193 French JA, Krauss GL, Biton V, et al. Adjunctive perampanel for refractory partial-onset seizures: randomized phase III study 304. Neurology 2012;79(6):589-596

194 Steinhoff BJ, Ben-Menachem E, Ryvlin P, et al. Efficacy and safety of adjunctive perampanel for the treatment of refractory partial seizures: a pooled analysis of three phase III studies. Epilepsia 2013;54(8):1481-1489

195 Krauss GL, Serratosa JM, Villanueva V, et al. Randomized phase III study 306: adjunctive perampanel for refractory partial-onset seizures. Neurology 2012;78(18):1408-1415

196 Wheless JW, Conry J, Krauss G, Mann A, LoPresti A, Narurkar M. Safety and tolerability of rufinamide in children with epilepsy: a pooled analysis of 7 clinical studies. J Child Neurol 2009;24(12): $1520-1525$

197 Glauser T, Kluger G, Sachdeo R, Krauss G, Perdomo C, Arroyo S. Rufinamide for generalized seizures associated with LennoxGastaut syndrome. Neurology 2008;70(21):1950-1958

198 Vendrame M, Loddenkemper T, Gooty VD, et al. Experience with rufinamide in a pediatric population: a single center's experience. Pediatr Neurol 2010;43(3):155-158

199 Moavero R, Cusmai R, Specchio N, et al. Rufinamide efficacy and safety as adjunctive treatment in children with focal drug resistant epilepsy: the first Italian prospective study. Epilepsy Res 2012;102(1-2):94-99

200 Lee EH, Yum MS, Ko TS. Effectiveness and tolerability of rufinamide in children and young adults with Lennox-Gastaut syndrome: a single center study in Korea. Clin Neurol Neurosurg 2013;115(7):926-929

201 Grosso S, Coppola G, Dontin SD, et al. Efficacy and safety of rufinamide in children under four years of age with drug-resistant epilepsies. Eur J Paediatr Neurol 2014;18(5): 641-645

202 Kaufman KR, Struck PJ. Activation of suicidal ideation with adjunctive rufinamide in bipolar disorder. Epilepsy Behav 2011;20(2):386-389

203 Cusmai R, Verrotti A, Moavero R, et al. Rufinamide for the treatment of refractory epilepsy secondary to neuronal migration disorders. Epilepsy Res 2014;108(3):542-546

204 Johannessen SI, Landmark CJ. Value of therapeutic drug monitoring in epilepsy. Expert Rev Neurother 2008;8(6): 929-939

205 Mula M, Sander JW. Suicide risk in people with epilepsy taking antiepileptic drugs. Bipolar Disord 2013;15(5): 622-627

206 Fountoulakis KN, Gonda X, Baghai TC, et al. Report of the WPA section of pharmacopsychiatry on the relationship of antiepileptic drugs with suicidality in epilepsy. Int J Psychiatry Clin Pract 2015;19(3):158-167

207 Machado RA, Espinosa AG, Melendrez D, González YR, García VF, Rodríguez YQ. Suicidal risk and suicide attempts in people treated with antiepileptic drugs for epilepsy. Seizure 2011;20(4): 280-284

208 Andersohn F, Schade R, Willich SN, Garbe E. Use of antiepileptic drugs in epilepsy and the risk of self-harm or suicidal behavior. Neurology 2010;75(4):335-340

209 Jones JE, Siddarth P, Gurbani S, Shields WD, Caplan R. Screening for suicidal ideation in children with epilepsy. Epilepsy Behav 2013;29(3):521-526

210 Caplan R, Siddarth P, Gurbani S, Hanson R, Sankar R, Shields WD. Depression and anxiety disorders in pediatric epilepsy. Epilepsia 2005;46(5):720-730 